\title{
"The GifTed Judge": AN ANALYSIS OF THE Judicial CAREer OF ROBERT H. JACKSON
}

\author{
GRAEME A. BARRY
}

The author undertakes an historical anabysis of the judicial achievements of Robert $H$. Jackson, Associate Justice of the United States Supreme Court from 1941 until his sudden death in 1954. Justice Jackson's approach to the nature of the judicial function, to judicial review and to the question of extrajudicial activities sheds light on contemporary debate in these areas. Despite being undoubtedly infuenced by his place on the "Roosevelt Court," Jackson was a strong individualist, which the author believes accounts for his "maverick" status on the Court. Justice Jackson's prominent judicial opinions relating to economic regulation, procedural due process, civil liberties and the separation of powers doctrine reveal how he addressed the inherent tension between judicial review and democracy in the American system of government. The effects of extrajudicial activities are explored with reference to his key role at the Nuremberg Trials, and the appointment of Madam Justice Louise Arbour to serve as Prosecutor for the International Criminal Tribunals.
L'auteur entreprend une analyse historique des réalisations judiciaires de Robert $H$. Jackson, juge associé de la Cour suprême des Etats-Unis de 194I jusqu'à sa mort en 1954. L'approche du juge Jackson à l'égard de la nature de la fonction judiciaire, de la révision judiciaire et de la question des activités extrajudiciaires éclaircit le débat contemporain en la matière. Malgré le fait qu'il ne fait aucun doute qu'il a été influencé par sa situation à la "Cour de Roosevelt un grand individualiste, trait auquel l'auteur attribue le côté " non-conformiste (rebelle) " à la cour. Les fortes opinions émises par le juge Jackson en matière de régulation économique, d'application des règles de procédures, de libertés civiles et de la doctrine de séparation des pouvoirs révèlent sa manière de composer avec la tension inhérente qui existe entre la révision judiciaire et la démocratie dans le système américain de gouvernement. Les effets de ses activités extrajudiciaires sont examinés à la lumière du rôle clé qu'il a joué au procès de Nuremberg et de la nomination de Madame la juge Louise Arbour au poste de procureure des tribunaux pénaux internationaux.

\section{TABLE OF CONTENTS}

I. INTRODUCTION ................... 881

II. BIOGRAPHY AS REVELATION: A LIFE IN THE LAW . . . . . . 882

III. THEORY AND PRACTICE: GENERAL JUDICIAL PHILOSOPHY . . . . . 889

IV. WORDS AND DEEDS: SPECIFIC JURISPRUDENCE $\ldots \ldots \ldots \ldots \ldots 893$

A. ECONOMIC REgUlATION . . . . . . . . . . . . . . 894

B. Procedural Due Process and Civil liberties . . . . . 895

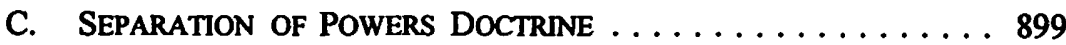

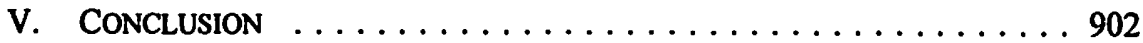

B.A., LL.B. (U.N.B.), M.A. (Toronto), LL.M., D.Jur. (Osgoode Hall).

The quotation in the title of this article is taken from Professor Paul Freund's tribute to Judge Leamed Hand in On Law and Justice (Cambridge, Mass.: Belknap Press, 1968) at 251. 


\section{INTRODUCTION}

Robert Houghwout Jackson became an Associate Justice of the United States Supreme Court on July $11,1941 .^{2}$ He served in that office until his sudden death on October 9, 1954. ${ }^{3}$ Court historians have ranked Jackson's judicial achievements as "near great." Therefore, much can be learned by those who select judges and by those who serve as judges through a closer examination of Jackson's judicial career.

Although it has been more than forty-five years since Jackson's death, such issues as the nature of the judicial function, the relationship of judicial review to democratic theory, and the effect of extrajudicial activities upon the reality and the perception of impartiality and independence still challenge members of the judiciary. Jackson's specific jurisprudence relating to economic regulation, procedural due process, civil liberties, and the separaticn of powers doctrine yields valuable insights to those who undergo the ordeal of judgment a half century later. Jackson is a human link between the legal past and the legal present. Justice Benjamin N. Cardozo served as one of his mentors, and Jackson was a mentor for William H. Rehnquist, the present Chief Justice of the United States.

Despite Jackson's complete lack of previous judicial experience, few new members in the history of the United States Supreme Court had the benefit of as much prior reflection regarding the judicial office. However, it is precisely because his judicial philosophy evolved during his lengthy legal and public service careers, and was influenced greatly by the powerful forces then operating in American legal and political thought, that it is difficult to grasp his outlook completely and to comprehend fully the extent of his influence. Fortunately, more recent legal, political science, and historical research have provided further information as to how history affected Jackson, and how he affected history.

Justice Jackson had received a practical education, was a fervent individualist, and possessed exceptional advocacy skills. During his service in the Roosevelt New Deal Administration, he developed a deep belief in the importance of judicial restraint. As the Chief Counsel for the United States at the Nuremberg War Crimes Trials, he acquired an insight into the horrific dangers of totalitarianism that affected his subsequent jurisprudence.

Jackson was determined to separate law from politics, and he employed procedure and neutral principles as his means to accomplish this purpose. Like others in American legal thought, he struggled to give legitimacy to his judicial review theory during the immediate aftermath of the clash between legal formalism and legal realism. His written

2 W. Cohen \& J.D. Varat, Constitutional Law: Cases and Materials, 10th ed. (Westbury, New York: Foundation Press, 1997) at 1715.

Ibid.

H.J. Abraham, Justices and Presidents: A Political History of Appointments to the Supreme Court (New York: Oxford University Press, 1974) at 219.

s Chief Justice Rehnquist served as a law clerk for Justice Jackson. See B. Woodward \& S. Armstrong, The Brethren: Inside the Supreme Court (New York: Avon Books, 1981) at 191. 
decisions were crafted carefully, and exhibit a literary skill that ranks with that of Justices Holmes and Cardozo. He was a prolific writer whose large number of concurrences and dissents indicates his maverick status among his colleagues.

Like Justice Cardozo, Justice Jackson adopted the style of a common law judge who applies a broad principle to the circumstances of a case with sensitivity, and adapts the theory to meet the practicalities of the situation. ${ }^{6}$ Because of this moderate adaptability, which was an essential element of Jackson's judicial philosophy, many view his constitutional approach as erratic when compared to the more simplistic or dogmatic conceptions of some of his colleagues. His adaptable method did contain an inherent element of unpredictability, for he was not an absolutist in interpreting constitutional rights, and he did not favour an extreme form of deference to the decisions of the political branches of the government. Throughout his judicial career, Justice Jackson's jurisprudence contained some contradictory aspects, as he reconsidered his opinions concerning the major constitutional controversies of his time. As Professor Freund observed: "His philosophy was, in the figure applied to the common law, working itself pure." Generally, Jackson's jurisprudence exhibits a deep concern "with balancing the values of continuity against those of improvement, certainty against adaptability, liberty against authority."

\section{BIOgRaphy as Revelation: A Life IN THE LAW}

Many of the elements which influenced Robert Jackson's conception of the judicial function can be traced to the lessons which he learned during his lengthy legal and public service careers. His practical education served as the firm foundation for his theoretical orientation.

Robert Jackson did not attend college, but instead commenced a three-year clerkship with a lawyer in preparation to enter the New York State Bar. ${ }^{9}$ During the clerkship, he went to Albany Law School and completed the two-year course in one year. In the afternoons, he often listened to arguments in the New York Court of Appeals. ${ }^{10} \mathrm{He}$ was admitted to the New York State Bar in 1913. " Jackson found the practice of law in Jamestown, New York, a "very hospitable profession." 12 He was encouraged by

6 J.R. Stoner, Jr., “ 'Constitutional Revolution' Revisited: Liberalism and the Common Law on the Roosevelt Court" (Southem Political Science Association, 9 November 1990) [unpublished] at 7. Freund, supra note 1 at 182 .

- E.C. Gerhart, America's Advocate: Robert H. Jackson (New York: Bobbs-Merrill Company, 1958) at 466, quoting from Justice Jackson's "Lawyer's Creed."

Ibid. at 30.

10 P.B. Kurland, "Robert H. Jackson" in L. Friedman \& F.L. Israel, eds., The Justices of the United States Supreme Court, 1789-1969: Their Lives and Major Opinions (New York: Chelsea House, 1969) at 2544.

$11 \quad$ Gerhart, supra note 8 at 35.

12 Kurland, supra note 10 at 2545 . The quotations in the Kurland article were taken from a transcript of taped interviews with Jackson prepared for the Oral History Project of Columbia University. Not all new members of the American or Canadian legal professions were welcomed with hospitality. Anti-Semitism was experienced by Justice Felix Frankfurter, Chief Justice Bora Laskin, and Ambassador Sol M. Linowitz, and anti-Catholicism by Edward Bennett Williams. See G.E. 
other members of the local bar, and he was never deterred by those who were envious of his budding professional talent.

Political activity quickly followed Jackson's entry into the legal profession. At the age of twenty-one, he was elected to the Democratic State Committee. ${ }^{13} \mathrm{He}$ detested deeply the organizational responsibilities of the position, especially the allocation of patronage appointments. To Jackson, people seeking political favours and waging political vendettas were a distraction from the practice of law. He did not offer for reelection upon the expiry of his term. His distaste for the organizational side of politics would have detrimental ramifications for future political aspirations. One undeniable benefit of his brief political tenure was the working relationship which he established with Franklin Delano Roosevelt. As the Assistant Secretary of the Navy in President Woodrow Wilson's Administration, Roosevelt was the contact person in Washington for the New York Democratic State Committee. ${ }^{14}$ Jackson travelled frequently to Washington in 1913 and 1914 in order to meet with Roosevelt and others regarding party patronage.

During twenty-one years of private practice, Jackson developed outstanding advocacy skills, and the pragmatic approach of a generalist practitioner. His professional success was accompanied by financial independence and leadership positions in the bar associations. He declined Governor Roosevelt's offer of appointment to the Public Service Commission of New York. ${ }^{15}$ When Franklin Roosevelt became President in 1933, his New Deal Administration required experienced professionals. In 1934, Jackson's public career commenced when he accepted appointment to the Treasury Department as the General Counsel of the Bureau of Internal Revenue. ${ }^{16}$ Subsequently, he served as head of the tax and anti-trust divisions at the Department of Justice. ${ }^{17}$ Like others who agreed to join the New Deal Administration, Jackson planned to stay in Washington less than six months. ${ }^{18}$ He remained there for the rest of his life.

Politically, Jackson was associated with the "left-wing" of the New Deal, and he was among the President's fishing and poker playing companions. ${ }^{19}$ He was active in supporting Roosevelt in the 1936 presidential campaign. He shared President Roosevelt's frustration with the Supreme Court's lack of deference to the political branches in its opposition to the New Deal programs, and he supported the President's

White, Justice Oliver Wendell Holmes: Law and the Inner Self (New York: Oxford University Press, 1993) at 356; 1. Abella, "The Making of a Chief Justice: Bora Laskin, The Early Years" in F.E. McArdle, ed., The Cambridge Lectures, 1989 (Montréal: Editions Yvon Blais, 1990) at 162; S.M. Linowitz, The Betrayed Profession: Lawyering at the End of the Twentieth Century (New York: Charles Scribner's Sons, 1994) at 5-6; and E. Thomas, The Man to See: Edward Bennett Williams: Ultimate Insider; Legendary Trial Lawyer (New York: Simon \& Schuster, 1991) at 4243.

Kurland, supra note 10 at 2545.

Ibid.

Ibid. at 2546.

Gerhart, supra note 8 at 66 .

lbid. at 83-88.

Kurland, supra note 10 at 2543.

lbid. at 2550 and 2555. 
"court-packing plan." In 1937, Jackson informed Roosevelt of his intention to end his public career, and to return to private practice. The President asked Jackson to remain with the Administration and to be a candidate for Governor of New York in 1938, so that Jackson might be positioned to seek the presidency in 1940. Despite the President's support, the organization politicians in New York led by Postmaster General James B. Farley, who harboured his own presidential aspirations, opposed Jackson's proposed candidacy. The incumbent Democratic Governor announced his intention to seek another term, which effectively ended Jackson's electoral career before it officially began. ${ }^{20}$

In 1938, Jackson was appointed Solicitor General, ${ }^{21}$ and two years later he was selected as the Attorney General. ${ }^{22}$ In his capacity as Solicitor General, he argued twenty-four cases before the Supreme Court and lost only one. ${ }^{23}$ His advocacy skills were so impressive that Justice Louis Brandeis remarked that Jackson should be Solicitor General for life. ${ }^{24} \mathrm{He}$ served as counsel to the President in helping to draft the Neutrality Proclamation and the Executive Order declaring a partial state of emergency at the commencement of war in Europe. ${ }^{25}$ Jackson also prepared a formal legal opinion which supported the President's decision to exchange decommissioned destroyers for bases with Great Britain without further congressional authorization. ${ }^{26}$ Overall, Attorney General Jackson regarded the President as his client. Roosevelt respected Jackson's opinion because he was not a simpering sycophant. As Attorney General, Jackson believed that he never had to tailor his opinions in order to suit the President's desires. ${ }^{27}$

When Chief Justice Charles Evans Hughes retired in 1941, it was rumoured that Jackson would be chosen as his successor. Roosevelt consulted Hughes who believed that the next Chief Justice should be selected from among the Supreme Court Justices. Hughes favoured the elevation of Justice Harlan Fiske Stone. ${ }^{28}$ Stone had been Attorney General in the Coolidge Republican Administration, and the Dean of

Ibid. at 2555-56. See also T.H. Watkins, Righteous Pilgrim: The Life and Times of Harold L. Ickes, 1874-1952 (New York: Henry Holt and Company, 1990) at 677. Watkins quotes from a letter dated June 1, 1939 from Secretary of the Interior Ickes to Anna Boettiger, President Roosevelt's only daughter: "Bob Jackson would make a fine President. He is not only a thoroughgoing liberal, he is a convinced liberal. He knows what it is all about and he has poise and strength and character.... But Bob did not make the grade [for the Govemorship of New York] and I can't see him for 1940." Jackson's presidential aspirations are also mentioned briefly by the President's son, Elliott Roosevelt, and James Brough in A Rendezvous With Destiny: The Roosevelts of the White House (New York: Dell, 1976) at 263. Doris Kearns Goodwin notes that Roosevelt encouraged Jackson as well as several other possible candidates, but the master conjurer committed himself to no one. See D. Kearns Goodwin, No Ordinary Time: Franklin and Eleanor Roosevelt: The Home Front in World War II (New York: Simon \& Schuster, 1994) at 107. W.W. Gardner, "Government Attorney" (1955) 55 Columbia L. Rev. 438 at 441. G. Schubert, Dispassionate Justice (New York: Bobbs-Merrill Company, 1969) at 13. R. Kluger, Simple Justice (New York: Alfred A. Knopf, 1976) at 235.

Gerhart, supra note 8 at 191.

Kurland, supra note 10 at 2558.

Ibid. at 2560-61.

lbid. at 2561 .

lbid. at 2562. 
Columbia University Law School. ${ }^{29}$ For national unity reasons on the eve of America's entry into World War II, Roosevelt elevated Stone to Chief Justice and appointed Jackson as an Associate Justice. Justice Jackson was viewed by many as Chief Justice Stone's heir apparent. This aroused envy in some of Jackson's colleagues, and probably contributed to the circumstances that influenced both the content of his judicial review theory and the diminished impact which it had upon the other Justices' opinions. Reflecting later upon his relationship with his colleagues, Jackson remarked:

I was enjoying my work as Associate Justice but I could see that if I were promoted to Chief Justice over New Dealers who'd been on the Court longer, there was going to be the bitterest feeling. In fact, rumor had gone around that there was some commitment to me. It made my work very difficult, because others had a very strong feeling that they, as seniors on the Court, were entitled to consideration ahead of me.... It seemed to me that the retirement of Stone would precipitate an unpleasant situation for me.... ${ }^{30}$

Four years following his appointment to the Supreme Court, Jackson took a leave of absence from the Court, and accepted President Harry Truman's invitation to serve as the United States Representative and Chief of Counsel at the Nuremberg War Crimes Trials. ${ }^{31}$ He negotiated the Charter on which the Trials were based, prepared the evidence supporting the charge that the Nazis planned and waged a war of aggression, gave the opening and closing statements for the prosecution, and took part in the crossexamination of several accused, including Goering and Speer. ${ }^{32}$

His experience at Nuremberg gave Jackson insight into the terrifying dangers of totalitarianism, which had a significant influence upon specific aspects of his subsequent jurisprudence. He could not look upon the depths of human sadism and suffering and not be moved. Justice Jackson gained a greater appreciation of procedural due process. However, he took a narrower view of the scope of some civil liberties when weighed against the need for public order. ${ }^{33}$ In his opinion, this balance had not been maintained properly in the Weimar Republic, which permitted the Nazi Party's rise to power. In assessing his own legal career, Jackson considered his eighteen months at Nuremberg as "the most important, enduring and constructive work of my life."

Jackson's leave of absence from the Supreme Court in order to perform his advocacy duties at Nuremberg exacerbated an already tense relationship with some of his

A.T. Mason, Harlan Fiske Stone: Pillar of the Law (New York: Archon Books, 1968) at 144. Kurland, supra note 10 at 2563. It is not only in physics that every action is opposed by an equal reaction. My observation is a political adaptation of Law III of Sir Isaac Newton's three laws of motion. See S. Chandrasekhar, Newton's Principia for the Common Reader (Oxford: Clarendon Press, 1995) at 23.

Ibid. at 2566.

J.D. Hockett, "Justice Robert H. Jackson, The Supreme Court and the Nuremberg Trial" [1990] The Supreme Court Review 257 at 257.

Ibid. at 287-94. See J.D. Hockett, New Deal Justice: The Constitutional Jurisprudence of Hugo L. Black, Felix Frankfurter, and Robert H. Jackson (Lanham, Maryland: Rowman \& Littlefield Publishers, 1996) at 267-71 and 278-79 [hereinafter New Deal Justice].

T. Taylor, "The Nuremberg Trials" (1955) 55 Columbia L. Rev. 488 at 488. 
colleagues. Chief Justice Stone had not been consulted regarding Jackson's appointment. ${ }^{35}$ Moreover, Stone viewed the Nuremberg Trials not as an historical landmark in international law, but as an illegitimate process by which the victors could punish the vanquished. He refused to administer the oath to the American representative on the panel of judges, ${ }^{36}$ and confided privately:

Jackson is away conducting his high-grade lynching party in Nuremberg. I don't mind what he does to the Nazis, but I hate to see the pretense that he is running a court and proceeding according to common law. This is a little too sanctimonious a fraud to meet my old-fashioned ideas. ${ }^{37}$

The grounds of Stone's opposition included disapproval of extrajudicial activities by a Supreme Court Justice, the legal and political ramifications of the Nuremberg Trials, and the increased judicial workload caused by Jackson's absence. ${ }^{38}$ Justice Douglas was in agreement with the Chief Justice's objections. ${ }^{39}$ Balanced against these objections is the potential to widen the judicial perspective, and the skills which a gifted judge such as Jackson could bring to the proceedings. ${ }^{40}$ Near the end of his life, Jackson conceded that Stone was correct to object to his extended absence from the Court, but he never regretted his work at Nuremberg: "I was entirely willing to quit the Court if this was the price. In those days this wasn't a pleasant place to be."

Justice Jackson's controversial involvement in the Nuremberg Trials as an advocate while still remaining a member of the United States Supreme Court is important for more than the purposes of historical curiosity. A similar controversy arose when the Security Council of the United Nations announced its appointment of Madam Justice Louise Arbour, then a member of the Ontario Court of Appeal, to serve as Prosecutor for the International Criminal Tribunals for the former Yugoslavia and for Rwanda in February, $1996 .{ }^{42}$ The federal government sought to amend the Judges $A c t^{43}$ to permit a federally appointed judge with the approval of the Canadian Judicial Council to take a leave of absence without pay, and to accept remuneration and expenses from international agencies. ${ }^{44}$ Essentially, similar objections to those articulated by United States Chief Justice Stone were reiterated in the Canadian Senate debate, and Justice

Mason, supra note 29 at 715.

lbid.

lbid. at 716.

Ibid. at 718.

W.O. Douglas, The Court Years, 1939-1975: An Autobiography of William O. Douglas New York: Random House, 1980) at 28-29. Frankfurter supported Jackson's absence from the Court in order to be a prosecutor at Nuremberg. See M. Freedman, Roosevelt \& Frankfurter: Their Correspondence, 1928-1945 (Boston: Little, Brown and Company, 1967) at 662. Learned Hand, who opposed Jackson's role, argued vigorously with Frankfurter regarding this issue.

These countervailing considerations are explored in Hockett, supra note 32.

Mason, supra note 29 at 716.

The Honourable Madam Justice Louise Arbour, online: Supreme Court of Canada <http://www.scc-csc.gc.ca/brochure/english/html/Arbour.htm> (date accessed: 15 October 1999). Judges Act, R.S.C. 1985, c. J-1.

Debates of the Senate (19 June 1996) at 765 (Senator John G. Bryden). 
Jackson's experience was mentioned. ${ }^{45}$ The bill was subsequently amended so that the change regarding a leave of absence specifically referred to Madam Justice Louise Arbour by name, and not to all federally appointed judges. ${ }^{46}$

Chief Justice Stone died in April, 1946 while Jackson was still at Nuremberg. Once again, he was a leading candidate to become Chief Justice of the United States. However, it was reported that Justices Black and Douglas had made it known to President Truman that if Jackson were appointed Chief Justice, they would resign from the Court. ${ }^{47}$ President Truman nominated Fred Vinson, his Secretary of the Treasury, to be the new Chief Justice. ${ }^{48}$ Having been passed over for the second time because of Machiavellian machinations, Jackson sent a cable from Nuremberg on June 10, 1946 to the congressional judiciary committees. In this controversial cable, he criticized Justice Black for not recusing himself from one case because of a possible conflict of interest, and for exerting partisan pressure upon the Court to release a decision earlier than scheduled so as to influence labour negotiations. ${ }^{49}$ This dispute revealed Jackson's great anger regarding the political infighting among the Justices, and his deep revulsion at the overt mixture of law and partisan politics. More importantly, the incident highlighted the major ideological rifts in the "Roosevelt Court." Following the judicial acceptance of most of the New Deal, the Court's ambitious members shared few points of unity.

Hugo LaFayette Black was a Democratic Senator from Alabama prior to his nomination as an Associate Justice by President Roosevelt. He was also an ardent supporter of both the New Deal programs and the "court-packing plan." Black's nomination was so controversial that it was referred to the Senate Judiciary Committee for full hearings. The Senate had not employed this procedure regarding the Supreme Court nomination of a senator since 1888. Although Black was confirmed despite the admission of a two-year membership in the Ku Klux Klan, there were lingering misgivings that he possessed marginal legal skills and strong political loyalties. ${ }^{50}$ Justice Stone wrote to Professor Frankfurter concerning Justice Black:

Debates of the Senate (1 October 1996) at 894-897 (Senator Anne C. Cools), and Debates of the Senate (28 October 1996) at 1009-1013 (Senator Anne C. Cools). See 1012 for the reference to Jackson.

An Act to Amend the Judges Act and to Make Consequential Amendments to Another Act, S. C. 1996, c. 30, s. 5. Ironically, royal assent was given to this bill, which concemed the separation of powers, by Mr. Justice John Major of the Supreme Court of Canada in his capacity as Deputy Governor General. See Debates of the Senate (28 November 1996) at 1228. Recently, the Canadian Judicial Council has advised federally appointed judges to exercise caution in accepting "tasks which take them away from the regular work of their courts." See Canadian Judicial Council, Ethical Principles for Judges (Ottawa: Canadian Judicial Council, 1998) at 18-19. supra note 39 at 29. Professor Kurland has stated that Justice Black's position was communicated through intermediaries. See Kurland, supra note 10 at 2569. 
He needs guidance from someone who is more familiar with the workings of the judicial process than he is. With guidance, and a disposition to follow it until he is a little surer of himself, he might do great things. I am fearful though that he will not avoid the danger of frittering away his opportunity for judicial effectiveness by lack of good technique, and by the desire to express ideas which, however valuable they may be in themselves, are irrelevant or untimely. There are enough present-day battles of importance to be won without wasting our efforts to remake the Constitution $a b$ initio, or using the judicial opinion as a political tract. ${ }^{\text {st }}$

Although Justices Black and Jackson had been supporters of the New Deal, they extracted far different lessons from their political experiences which affected their judicial philosophies, and made them adversaries on the Supreme Court. Justice Black was a judicial activist who favoured certain social reforms, and would interpret the Constitution and statutes in order to support the reforms. Justice Jackson fought the judicial activism that had opposed the New Deal. Believing that judicial activism was a double-edged sword, he asserted that activism "was no more appropriate on the part of the judiciary in favor of reforms than it was in knocking them down. The initiative should remain with the legislative branch." ${ }^{52}$

From his lengthy legal and public service careers, Justice Jackson had acquired a practical education, fervent individualism, exceptional advocacy skills, political affiliations, professional leadership experience, admiration for judicial restraint, insights into totalitarianism, and revulsion against partisan political manipulation in the Supreme Court. All of these elements affected his jurisprudence. He was twice gifted. He possessed natural abilities, which when developed, produced a skilful legal mind. Second, these abilities were accorded the opportunities to flourish. It was Franklin Roosevelt, "that hero who was both larger than life and all too humanly imperfect, ... [who] gifted him with a share in the greatness of an age." 53

Having suffered a serious heart attack in the spring of 1954, Justice Jackson was cautioned to slow his pace. Preferring to maintain an active lifestyle, he did not generally follow this advice. On October 9,1954 , shortly following the commencement of the Supreme Court's new term, death came for Robert H. Jackson.

31 Mason, supra note 29 at 469. Stone's comment is also discussed by M.E. Parrish in Felix Frankfurter and His Times: The Reform Years (New York: Free Press, 1982) 276-77.

32 Kurland, supra note 10 at 2564-65. Jackson realized that many revolutionaries often come to resemble those whom they have overthrown once they have acquired power. This was also true of the "constitutional revolution" of 1937. George Orwell noted this trend toward transformation in the final scene depicted in the political fable Animal Farm, in which the ruling pigs resemble the human farmers, and "it was impossible to say which was which." See G. Orwell, Animal Farm (New York: Penguin Books, 1981) at 120.

33 Watkins, supra note 20 at 822 . This was Watkins' description of Roosevelt's relationship with Secretary Ickes. Doris Kearns Goodwin claims that the Roosevelt years "witnessed the most profound social revolution in the country since the Civil War - nothing less than the creation of modern America." See Goodwin, supra note 20 at 624. 


\section{Theory and Practice: General Judiclal Philosophy}

Justice Jackson authored two books that serve as pivotal markers in the evolution and expression of his judicial review theory. The Struggle for Judicial Supremacy was published in 1941, which was the year of his appointment to the Supreme Court. ${ }^{54}$ The Supreme Court in the American System of Government was prepared by Jackson as a series of lectures immediately prior to his death in $1954 .^{55}$

In The Struggle for Judicial Supremacy, which was written at the suggestion of President Roosevelt as an account of the conflict between the Roosevelt New Deal Administration and the Supreme Court, ${ }^{56}$ Jackson described the philosophy, interest, and training of the legal profession as tending toward conservatism. ${ }^{57} \mathrm{He}$ acknowledged the valuable role of the judiciary in the peaceful ordering of society, but unequivocally declared the need for judicial restraint. ${ }^{58}$ In his view, the New Deal changes did not require a revolution in the law, but a return to the older judicial values of the pre-Lochner Court. He declared:

With us, what is wanted is not innovation, but a return to the spirit with which our early judges viewed the function of judicial review of legislation - the conviction that it is an awesome thing to strike down an act of the legislature approved by the Chief Executive, and that power so uncontrolled is not to be used save where the occasion is clear beyond fair debate. ${ }^{59}$

In The Supreme Court in the American System of Government, Jackson expressed his more developed thoughts regarding the power of the institution of which he was a member. The theme of judicial deference is still pervasive, but the book is less a political propaganda tract than a sophisticated and practical consideration of the Supreme Court's functions. Jackson believed that the Supreme Court was a unit of a complex, interdependent scheme of government. Its independence, power, and effectiveness were limited by various factors. ${ }^{60} \mathrm{He}$ admitted candidly that the Supreme Court did function as a political institution, but its political concern was policy-making not partisanship. The Court could perform this function effectively by maintaining the various balances in the American democracy. These included the balance between the executive and the legislature, the national government and the state governments, and the majority and the individual. ${ }^{61}$

Jackson presupposed that the Court would exercise strict self-discipline, and would not depart from the judicial process, go beyond cases or controversies, or deliberately

R.H. Jackson, The Struggle for Judicial Supremacy (New York: Alfred A. Knopf, 1941) [hereinafter The Struggle for Judicial Supremacy].

R.H. Jackson, The Supreme Court in the American System of Government (Cambridge: Harvard University Press, 1955) [hereinafter The Supreme Court].

Kurland, supra note 10 at 2553. Extensive assistance was provided by Paul Freund.

The Struggle for Judicial Supremacy, supra note 54 at 313.

Ibid.

Ibid. at 323.

The Supreme Court, supra note 55 at 10-11.

Ibid. at 61 . 
"encroach upon the functions of its coordinate branches." $62 \mathrm{He}$ sensed the persistent tension between judicial review and democracy, and expressed it as follows:

Judicial power to nullify a law passed by the representative process is a restriction upon the power of the majority to govern the country. Unrestricted majority rule leaves the individual in the minority unprotected. This is the dilemma and you have to take your choice. The Constitution-makers made their choice in favor of a limited majority rule. ${ }^{63}$

Justice Jackson believed this tension between judicial review and democracy to be inherent in the American system of government. He acknowledged that in interpreting constitutional limitations upon democracy, the Supreme Court made and altered the law of the Constitution. Because of its interference with the democratic process, judicial review had to be exercised with great caution. He stated his opinion of the Court's role in relation to the political branches clearly:

My philosophy has been and continues to be that such an institution, functioning by such methods, cannot and should not try to seize the initiative in shaping the policy of the law, either by constitutional interpretation or by statutory construction.... [T] There is a limit beyond which the Court incurs the just charge of trying to supersede the law-making branches. ${ }^{64}$

Jackson's judicial philosophy was influenced significantly by his admiration for Mr. Justice Benjamin N. Cardozo. As a New York practitioner, Jackson had known Cardozo who had served eighteen years on the New York Court of Appeals before his elevation to the Supreme Court. ${ }^{65}$ In 1930 Cardozo had supported Jackson's application for membership in the American Law Institute. ${ }^{66}$

Cardozo subscribed to Holmes' view that the Constitution must not "become the partisan of a particular set of ethical or economical opinions" which are not held by all.67 Although favouring flexibility in constitutional interpretation, Cardozo rejected the position of the radical legal realists who in his view "exaggerate[d] the indeterminancy ... [and] treat[ed] the random or chance element as a good in itself ... [which] exceed[ed] in value the elements of certainty and order and rational coherence."168 As a legal theoretician, Cardozo has been described as "thoroughly

Ibid. at 61-62.

Ibid. at 79.

Ibid. at 79-80.

D.N. Atkinson, "Mr. Justice Cardozo: A Common Law Judge On a Public Law Court" (1980), 28 Chitty's L.J. at 211.

66 Gerhart, supra note 8 at 289.

67 Holmes J. in Otis v. Parker, 187 U.S. 606, at 608-609 (1902). This was the first opinion which Holmes delivered as a Supreme Court Justice that indicated his position regarding judicial review of the constitutionality of statutes. This approach was repeated in his seminal dissent in Lochner v. New York, 198 U.S. 45, 75 (1905). For a more detailed discussion see White, supra note 12 at 323-328. Benjamin Cardozo quoted from Holmes' decision in Otis with approval in The Nature of the Judicial Process (New Haven: Yale University Press, 1968) at 89. 
pragmatic, suspicious of absolutes, and yet always respectful of traditional ways."69 This description is equally applicable to Justice Jackson. Like Cardozo, Jackson sought to reshape existing doctrine to meet a changing social environment. He was not an absolutist in the interpretation of constitutional rights, and he did not favour extreme deference to the political branches. Unlike Justices Black and Douglas, who tended to resolve constitutional uncertainties with broad strokes of the pen, or Justice Frankfurter who embraced a dogmatic deference, Jackson believed that the political branches had to be accorded adequate room in which to act, but that the Court must not become so complacent that the concept of constitutional limitation became an illusion. ${ }^{70}$

In The Transformation of American Law, 1870-1960, Morton Horwitz describes some of the forces that were operating in American legal thought during the era in which Robert Jackson formulated his judicial review theory. ${ }^{71}$ Horwitz believes that the New Deal constitutional revolution caused a fundamental shift in legal thought. Echoing Jackson's opinion in The Struggle for Judicial Supremacy, according to Horwitz, this fundamental shift "was justified not as a powerful break with the old order, but as a conservative restoration of neutral constitutional principles...." 72 In Horwitz's analysis, the three broad influences present in post-WWII legal thought included various reactions to the legacy of legal realism, different views regarding the emergence of totalitarianism, and an attempt to reconcile the Supreme Court decision in Brown v. Board of Education ${ }^{73}$ with the post-Lochner commitment to judicial restraint. ${ }^{74}$ Because Robert Jackson was a representative man in the American legal profession, he was influenced by all three forces in varying degrees in the evolution and application of his judicial review theory.

During this period, there was persistent pressure from the legal profession to restore a sharp distinction between law and politics, which had been shaken by the clash of legal formalism with legal realism. Jackson's effort to restore this division is revealed in his approach to statutory interpretation, and in his search for neutral principles. With the aid of the common law method, he attempted to draw a line between judicial and legislative functions, so as to minimize the policy-making role of the courts:

But to observe the democratic separation of functions so as to leave policy-making to the political bodies and make the function of interpretation a professional matter, requires training, constant intellectual effort, deliberation and detachment. And it is guided and aided by the experience of generations of common law judges found in the precedents. ${ }^{75}$

69 Atkinson, supra note 65 at 223.

to R. McCloskey, The American Supreme Court (Chicago: University of Chicago Press, 1960) at 227 231. For those who claimed that Jackson's style was unpredictable see Hutchinson, supra note 49 at 241, and C.H. Pritchett, The Roosevelt Court (New York: Macmillan Company, 1969) at 131. M.J. Horwitz, The Transformation of American Law, 1870-1960: The Crisis of Legal Orthodoxy (Oxford: Oxford University Press, 1992) at 247.

lbid. at 7 .

347 U.S. 483 (1954) [hereinafter Brown].

Ibid. at 247.

R.H. Jackson, "The Meaning of Statutes: What Congress Says or What the Court Says" (1948), 34 American Bar Association Journal 535 at 536-37. 
As has been noted, Justice Jackson eventually recognized that limited policy-making was a part of the judicial function. Like others involved in the judicial process, his theoretical conceptions were evolving and not neat.

In post-WWII legal and political thought, there were also two major reactions to the emergence of totalitarianism. Consensus theorists, led by Robert Dahl, attempted to locate societal norms in widely shared customs and conventions. The advocates of consensus in law emphasized the importance of procedure. This was consistent with the legal process school. Judicial discretion would be harnessed and channelled through institutional arrangements. ${ }^{76}$ Equilibrium theorists, on the other hand, claimed that agreement would emerge among different and competing groups, and tended to emphasize value-free neutral principles that could legitimize decisions independently from their results. ${ }^{77}$

In his judicial review theory, Justice Jackson did not appear to choose between the two schools, for he employed the techniques of both, which was characteristic of his eclectic style. In a speech before the Canadian Bar Association, Jackson, who had a deep belief in procedural due process, seemed to adopt the underlying consensus theory as the "foundation of society." 78 However, his approach to statutory construction, according to which the judge is independent of the competing interests in applying disinterested principles, is similar to the neutral principles technique of the equilibrium theorists. Jackson's perception of the judicial office reflected a striving for human objectivity:

Something does happen to a man [woman] when he [she] puts on a judicial robe, and I think it ought to. The change is very great and requires psychological change within a man [woman] to get into an attitude of deciding other people's controversies instead of waging them. It really calls for quite a changed attitude. Some never make it - and I am not sure I have.

...The kind of judge we admired was a man [woman] that didn't let the personalities on either side interfere with his [her] deciding the case on the facts and the law... The interpretation of the law ought to be as impersonal as possible. ${ }^{79}$

Finally, the third force which influenced post-WWII legal thought, and by implication, Justice Jackson's judicial review theory, was the attempt to reconcile the Brown decision with judicial restraint. Jackson did not issue a separate opinion in Brown, but joined the unanimous opinion written by Chief Justice Warren. However, he did write a memorandum that revealed the struggle which he experienced in reconciling his decision to strike down segregation in education as unconstitutional with his judicial review theory that the Court should not seize the initiative in shaping the Ibid. at 251-52. R.H. Jackson, "An Address" (1944), 22 Can. Bar Rev. 173 at 175, quoting Lord Balfour with approval.

$79 \quad$ Kurland, supra note 10 at 2563.
} 
policy of the law, either by constitutional interpretation or by statutory construction. ${ }^{80}$ Jackson feared that the Court was ahead of the political branches of the government and large segments of the public on the issue. Although he did not doubt the correctness of his decision, he queried if the Court's leadership was the most effective means by which the noble purpose could be achieved.

In his memorandum, Jackson acknowledged explicitly that the Constitution is more easily changed than social customs. According to the existing law, segregation was not unconstitutional. Although the Fourteenth Amendment did contemplate changing conditions, it was Congress' responsibility to enact the necessary legislation. Finally, he invoked the doctrine of changing conditions as the legal basis for declaring segregation in education unconstitutional. He cited Cardozo's comment that the majestic generalities of the Constitution "have a content and a significance that vary from age to age." Wi With exceptionally accurate foresight, Jackson predicted the subsequent generations of litigation, and the requirement that the political branches act to prevent the Court's order from becoming a "dead letter." He observed prophetically: "With no machinery except that of the courts to put the power of the Government behind it, it seems likely to result in a failure that will bring the Court into contempt and the judicial process into discredit." ${ }^{82}$

Although he had suffered a serious heart attack on March 30, 1954, Jackson left the hospital on May 17, 1954 to be present with the other members of the Court when the Brown decision was announced in order to indicate the solidarity of the Justices. His memorandum was not issued as a concurrence probably because of his poor health, and a desire not to weaken the Warren opinion. The content of the memorandum may have provided a stronger legal basis for the decision because it avoided sociological studies and acknowledged the legal difficulties. ${ }^{83}$ However, it was less positive in tone than the Warren opinion, and still contained a serious inconsistency between its strong judicial initiative and Jackson's view of the Supreme Court's function in the American system of government.

\section{WORDS AND DEEDS: SPECIFIC JURISPRUDENCE}

Jackson's written decisions are replete with rhetorical devices that add strength to the expression of his judicial review theory. He is the peer of Justices Holmes and Cardozo in literary ability. There is an intellectual vibrancy that pulsates through his prose. During his thirteen terms on the Supreme Court, he wrote one hundred and fifty-two

R.H. Jackson, "Memorandum on the Segregation Cases" (February 1954) [unpublished] [hereinafter Segregation Memorandum].

$81 \quad$ Kluger, supra note 23 at 689.

82 Segregation Memorandum, supra note 80 at 12.

s3 J.D. Hockett, "Justice Robert H. Jackson and Segregation: A Study of the Limitations and Proper Basis of Judicial Action" [1989] Supreme Court Historical Society Yearbook 52, especially at 5960; see also B. Schwart, "Chief Justice Rehnquist, Justice Jackson and the Brown Case" [1988] The Supreme Court Review 245 at 265-67. The struggle which Jackson experienced with Brown is similar to the difficulties described subsequently by Professor Herbert Wechsler in "Toward Neutral Principles of Constitutional Law" (1959) 73 Harvard L. Rev. I. 
opinions for the Court, one hundred and nine dissents, and fifty-four concurrences. ${ }^{84}$ The comparatively large number of dissents and concurrences indicates his maverick status among his colleagues which reduced the influence of his judicial review theory. He sensed this shortcoming in his last book:

The right of dissent is a valuable one.... But there is nothing good, for either the Court or the dissenter, in dissenting per se. Each dissenting opinion is a confession of failure to convince the writer's colleagues, and the true test of a judge is his influence in leading, not in opposing, his court. ${ }^{\text {ss }}$

An examination of Jackson's more prominent decisions concerning economic regulation, procedural due process, civil liberties, and the separation of powers doctrine reveals some of the elements of his judicial review theory in action.

\section{A. ECONOMic Regulation}

When Jackson joined the Supreme Court in the summer of 1941, the "constitutional revolution" which had begun in 1937 was in motion. ${ }^{86}$ Legal realism was one aspect of an intellectual movement against formalistic thought which gained influence during the early part of the twentieth century. Although some of its roots may be traced to the skepticism found in the legal philosophy of Oliver Wendall Holmes Jr., ${ }^{87}$ the severe economic crisis of the Great Depression provided substantial impetus for the ascendancy of legal realism. The governmental response to the crisis caused changes in the perceptions of federalism, the laissez-faire economy, and the doctrine of delegation. The political pressures exerted upon the Court by the results of the 1936 presidential election in which President Roosevelt won forty-six of the forty-eight states, ${ }^{88}$ and the President's submission of his plan to reorganize the federal judiciary, must not be underestimated. ${ }^{89}$ For instance, the majority of the Court chose to return to a wider view of the federal commerce power.

The Court also altered its position regarding judicial review. It abandoned the majority approach in Lochner. In United States v. Carolene Products, Justice Stone declared that the Court would uphold regulatory legislation "affecting ordinary commercial transactions" if it rested "upon some rational basis within the knowledge

s4

Gerhart, supra note 8 at 504, footnote 95. Richard Kluger contends that Jackson had "a pen with more grace and bite than any other ever wielded by a member of the Court." See Kluger, supra note 23 at 235.

85

B6

87

The Supreme Court, supra note 55 at 19.

P.W. Hogg, Constitutional Law of Canada, 4th ed. (Scarborough: Carswell, 1997) at 805.

Lord Lloyd of Hampstead and M.D.A. Freeman, Lloyd's Introduction to Jurisprudence, 5th ed. (London: Stevens \& Sons, 1985) at 680-84. There is an ongoing debate as to whether Holmes was an original legal realist. See White, supra note 12 at 365.

A.T. Mason \& D.G. Stephenson, Jr., American Constitutional Law, 9th ed. (New Jersey: Prentice Hall, 1990) at 193.

Ibid. Roosevelt proposed that a justice who reached seventy years of age would have to retire within six months. A justice could choose not to retire, but this would allow the President to appoint an additional justice, up to a maximum bench of fifteen judges. For a more detailed legal and political analysis of the "court-packing plan," see J. MacGregor Burns, Roosevelt: The Lion and the Fox (New York: Harcourt, Brace and Company, 1956) at 293-315. 
and experience of the legislators. ${ }^{900}$ The Court moved away from the rigid rules of legal formalism toward the flexibility of legal realism, resulting in greater deference to the legislature. During the "third great era of judicial history," the Court would become more concerned with civil rights and the relationship between the individual and the state. $^{91}$

In Wickard v. Filburn, the question of Congress' capacity to authorize a penalty for a farmer under the Agricultural Adjustment Act for growing more wheat than the Secretary of Agriculture had permitted was challenged as not coming under the Interstate Commerce Clause. ${ }^{92}$ Jackson upheld the federal statute, and revealed his New Deal sympathies. By rejecting the legal formulas of local and national, and direct and indirect, Jackson also indicated the influence of legal realism and the demise of legal formalism's rigid categories. Congress had the authority not only to control that which directly constituted interstate commerce, but also that which affected it. This opinion established firmly the capacity of Congress to regulate local economic processes because of the relevance of economic effects in the application of the Commerce Clause. Jackson never did invalidate an Act of Congress on the basis that it exceeded the federal power to control any part of the national economy. ${ }^{93}$

\section{B. Procedural Due Process and Civil liberties}

In his procedural due process jurisprudence, Jackson exhibited his sympathy with the attempts of the legal process school to control the discretion which legal realism had identified as an integral part of the judicial function. Through this control of discretion, Jackson attempted to express his post-Nuremberg appreciation of procedural due process, and to legitimate his judicial review theory.

In Shaughnessy v. United States ex rel. Mezei, a man was refused admission to several countries and was detained on Ellis Island. ${ }^{94}$ The Supreme Court majority recognized the sovereign power of the government to exclude aliens and the finality of executive decisions of this nature. Jackson dissented from this decision to defer to the executive and legislative branches. He described succinctly the dual purposes which procedural due process serves:

Procedural faimess and regularity are of the indispensable essence of liberty. Severe substantive laws can be endured if they are fairly and impartially applied... Let it not be overlooked that due process of law is not for the sole benefit of an accused. It is the best insurance for the Govemment itself against those blunders which leave lasting stains on a system of justice...."

o 304 U.S. 144 at 152 (1938) [hereinafter Carolene Products].

91 McCloskey, supra note 70 at 181 . See also Carolene Products, ibid. at 152, n. 4.

2 317 U.S. 111 (1942). See also A.E. Sutherland, "The Nation's Economy and State Frontiers" (1955) 8 Stanford L. Rev. 26 at 31-35.

93 Sutherland, ibid. at 34-35.

94345 U.S. 206 (1953). See also New Deal Justice, supra note 33 at 279.

95 Ibid. at 224-25. Professor Bickel described Jackson's dissent as "one of the last and one of the most brilliant of his opinions." See A.M. Bickel, The Least Dangerous Branch: The Supreme Court at the Bar of Politics (Indianapolis: Bobbs-Merrill Company, 1962) at 233. 
In civil liberty cases, Jackson sought to defend a passive right to internalize certain non-majoritarian views without having to reveal them. However, he was less sympathetic to those who desired to employ constitutional freedoms of speech and religion to proselytize. He protected a person's right to be left alone with his or her beliefs, but would limit a person's rights if they were used to interfere with others in order to have beliefs more widely shared. This was a direct outgrowth of his individualism. The abiding focus of his jurisprudence was the achievement of a balance between individual liberty and public order.

In West Virginia State Board of Education v. Barnette, ${ }^{96}$ a board of education ordered that all students be required to salute the flag and recite the pledge of allegiance or be expelled from school. The Jehovah's Witnesses objected on religious grounds. In one of his most eloquent decisions, Jackson delivered the majority opinion, overruled a precedent, and explained the rationale for judicial review in American democracy:

The very purpose of a Bill of Rights was to withdraw certain subjects from the vicissitudes of political controversy, to place them beyond the reach of majorities and officials and to establish them as legal principles to be applied by the courts. One's right to life, liberty, and property, to free speech, a free press, freedom of worship and assembly, and other fundamental rights may not be submitted to vote; they depend on the outcome of no elections."

Jackson's opinion was based primarily on freedom of thought. Although he appeared to adopt the Carolene Products footnote by stating that the freedoms may not be infringed on the "slender grounds" of the "rational basis" test, he had previously employed a traditional balancing test in Barnette. ${ }^{98} \mathrm{He}$ had noted that the freedom which was being claimed did not collide with the rights of others. He suggested that had there been a collision then the state could attempt to determine when the rights of one person ended and those of another began. Moreover, Jackson rejected the argument that the court's lack of specialized competence requires extreme deference to state action:

But we act in these matters not by authority of our competence but by force of our commissions. We cannot, because of modest estimates of our competence in such specialties as public education, withhold the judgment that history authenticates as the function of this Court when liberty is infringed.9

In American Communications Association v. Douds, Jackson was willing to override First Amendment rights to suppress union leaders who were Communists, but he dissented on the issue of the statutory provision that required a union officer to swear an oath that he did not believe in, or support any organization that believed in or taught the overthrow of the United States Government by force, or by any illegal or 
unconstitutional methods. ${ }^{100}$ To Jackson, this was the invasion of individual belief, and he denounced it in terms that could have applied to McCarthyism:

Communists are not the only faction which would put us all in mental strait jackets. Indeed all ideological struggles, religious or political, are primarily battles for dominance over the minds of people. It is not to be supposed that the age-old readiness to try to convert minds by pressure or suppression, instead of reason and persuasion, is extinct. Our protection against all kinds of fanatics and extremists, none of whom can be trusted with unlimited power over others, lies not in their forbearance but in the limitations of our Constitution. ${ }^{\text {:01 }}$

In his opinion in Douds, Jackson summarized his view of the Court's role in the dynamic environment of pendulum politics:

The task of this Court to maintain a balance between liberty and authority is never done, because new conditions today upset the equilibriums of yesterday. The seesaw between freedom and power makes up most of the history of governments which, ... on a long view consists of repeating a painful cycle from anarchy to tyranny and back again. The Court's day-to-day task is to reject as false, claims in the name of civil liberty which, if granted, would paralyze or impair authority to defend existence of our society, and to reject as false, claims in the name of security which would undermine our freedoms and open the way to oppression. These are the competing considerations involved in judging any measures which government may take to suppress or disadvantage its opponents and critics. ${ }^{102}$

Three cases demonstrate the influence on Jackson's judicial review theory of his Nuremberg experience and his insights into totalitarianism. He narrowed the freedom of speech in each case in order to establish what he perceived as a workable balance between individual liberty and public order.

In Kunz v. New York, a street corner preacher sought to have his conviction quashed for speaking without a permit. ${ }^{103}$ In his sermons, the preacher would often verbally attack Roman Catholics and Jews. The Supreme Court quashed the conviction as a violation of free speech. As the lone dissenter, Jackson would have placed limits upon freedom of speech. Obviously motivated by his Nuremberg experience, he foresaw future racial and religious strife:

It may become difficult to preserve here what a large part of the world has lost - the right to speak, even temperately, on matters vital to spirit and body. In such a setting, to blanket hateful and hatestirring attacks on races and faiths under the protections for freedom of speech may be a noble innovation. On the other hand, it may be a quixotic tilt at windmills which belittles great principles of liberty. Only time can tell. But $I$ incline to the latter view.... ${ }^{104}$

339 U.S. 382 (1950).

Ibid. at 438-39.

Ibid. at 445.

340 U.S. 290 (1951). See also New Deal Justice, supra note 33 at 269-70.

Ibid. at 295. 
In Terminiello v. Chicago, Jackson also warned the Court against an expansive interpretation of freedom of speech. ${ }^{105}$ Terminiello delivered a public address in which he criticized various racial and political groups, and several disturbances occurred. He was prosecuted for disorderly conduct that breached the peace. The majority quashed the conviction on procedural due process grounds and avoided the free speech issue. Jackson articulated his theory concerning the reconciliation of liberty with authority:

The choice is not between order and liberty. It is between liberty with order and anarchy without either. There is a danger that, if the Court does not temper its doctrinaire logic with a little practical wisdom, it will convert the constitutional Bill of Rights into a suicide pact. ${ }^{106}$

Finally, in Dennis v. United States, several national leaders of the Communist Party were tried and convicted for conspiring to advocate the overthrow of the United States Government by force. ${ }^{107}$ Jackson harboured a deep fear of Communism, and he equated its totalitarianism with Fascism, the leaders of which he had helped to prosecute at Nuremberg. He voted to uphold the convictions. He did not apply the Schenck test to limit free speech, because it had been formulated to deal with a problem other than a "well-organized, nation-wide conspiracy." Drawing upon his Nuremberg experience, Jackson noted the practical limitations of the judicial process to control political unrest:

Communism will not go to jail with these Communists. No decision by this Court can forestall revolution whenever the existing government fails to command the respect and loyalty of the people and sufficient distress and discontent is allowed to grow up among the masses. Many failures by fallen governments attest that no government can long prevent revolution by outlawry. ${ }^{109}$

Justice Jackson favoured a strong separation between religion and the state. He did not object to religion but to compulsion, which offended his independent disposition. In Everson v. Board of Education, the township had a policy of reimbursing parents for the cost of transporting their children by means of the local bus system to and from either public or Catholic parochial schools. ${ }^{110}$ The reimbursement came from tax revenues. The majority of the Court held that the case was not concerned with the establishment clause of the First Amendment, but with the free exercise clause, and it approved of the practice. Jackson dissented, and argued that the state could not reimburse individuals for receiving religious instruction. Though he believed that a court should normally defer to what the state wished to do with its money, in Everson he made it clear that the state could not make public business of religious worship or instruction. The establishment clause was intended 'to keep the states' hands out of

337 U.S. 1 (1949). See also New Deal Justice, supra note 33 at 269.

Ibid. at 37.

341 U.S. 494 (1951). See also New Deal Justice, supra note 33 at 277-78.

Ibid. at 567-69, and 577 .

lbid. at 578.

330 U.S. 1 (1947) [hereinafter Everson]. 
religion ... [and] to keep religion's hands off the state...."'I' It was through a religious test that the beneficiaries of the expenditure were selected.

\section{Separation of POWers Doctrine}

In both Korematsu v. United States 112 and Youngstown Sheet \& Tube Co. v. Sawyer, ${ }^{113}$ Jackson refused to defer to government action during a time of international conflict, because the action would harm civil liberties. In both decisions, Jackson exhibited his understanding that the judiciary is a weak branch of the government for the defence of civil liberties, and for the preservation of the separation of powers. He emphasized the limitations which he believed were inherent in the judicial function.

In Korematsu, a citizen of the United States of Japanese ancestry asked the Court to quash his conviction for failing to obey a military order made pursuant to an Executive Order and an Act of Congress. According to this military order, all persons of the Japanese "race" were to be removed from certain designated areas and to be resettled in internment camps. Under great public pressure, President Roosevelt had signed Executive Order 9066 authorizing the internment despite the opposition of his Attorney General. ${ }^{114}$ The majority of the Supreme Court upheld the conviction. Justice Black applied the Carolene Products footnote, and subjected the legal restrictions based on racial membership "to the most rigid scrutiny."1s However, he relied on the apprehended military dangers which were perceived by the government to satisfy this high standard. " of hardships." 117

In his dissenting opinion, Jackson conceded that military decisions were not susceptible to intelligent judicial review, but that did not mean that the civilian judiciary should be used to approve a military action as constitutional. ${ }^{118}$ Throughout Jackson's opinion, there is a struggle between his desire to uphold civil liberties and the legal maxim inter arma silent leges (in time of war the laws are silent). To Jackson's credit, his belief in the great value of civil liberties prevailed. Citing Justice Cardozo's concept that a principle will tend to expand to the limit of its logic, he voiced concern regarding

Ibid. at 26-27.

323 U.S. 214 (1944) [hereinafter Korematsu].

343 U.S. 579 (1952) [hereinafter Steel Seizure case].

Goodwin, supra note 20 at 322 . Pressure to act against Japanese Americans emanated from many political leaders including California Attorney General Earl Warren who later championed civil liberties in his capacity as Chief Justice of the United States. Eleanor Roosevelt opposed her husband's action, but was informed not to mention the matter again (ibid. at 323). Chief Justice Warren never expressed regret publicly during his life for his role in the internment, but he did state his regret in posthumously published memoirs. See B. Schwart, Super Chief: Earl Warren and His Supreme Court - A Judicial Biography (New York: New York University Press, 1983) at 14-17.

Korematsu, supra note 112 at 216.

Ibid. at 218.

Ibid. at 219.

Ibid. at 244. 
the use of the Court's prior holding in Hirabayashi v. United States which approved a curfew order as a basis for extending approval to the evacuation order. ${ }^{119}$ Jackson would not abdicate what he viewed as the Court's constitutional function of review in order to make the Court an instrument of military policy. He reiterated the belief that the Court possessed limited power, especially when it opposed the other two branches of government. He cautioned the people not to rely entirely on the judiciary to defend civil liberties. Mindful of the future dangers to civil liberties lurking in the majority opinion, he warned:

\begin{abstract}
Much is said of the danger to liberty from the Army program for deporting and detaining these citizens of Japanese extraction. But a judicial construction of the due process clause that will sustain this order is a far more subtle blow to liberty than the promulgation of the order itself. A military order, however unconstitutional, is not apt to last longer than the military emergency. Even during that period a succeeding commander may revoke it all. But once a judicial opinion rationalizes such an order to show that it conforms to the Constitution, or rather rationalizes the Constitution to show that the Constitution sanctions such an order, the Court for all time has validated the principle of racial discrimination in criminal procedure and of transplanting American citizens. ${ }^{120}$
\end{abstract}

In 1983, Fred Korematsu petitioned the district court at San Francisco to vacate his conviction on the ground that the original trial had been tainted by fundamental errors concerning whether the actions taken were reasonably related to the security and defence of the nation and the prosecution of the war. ${ }^{121}$ The petition for a writ of coram nobis was granted. ${ }^{122}$ Four decades following the Supreme Court decision from which Jackson had dissented vigorously, and three decades after Jackson's own death, his opinion was vindicated. Jackson stood against the President he had served, the Congress, the Army, and public opinion. Although he was being considered for the position of Chief Justice, he did not succumb to the temptation of the "inner ring," the desire to be on the inside that entices generally good people to do very bad things. ${ }^{123}$

Youngstown Sheet \& Tube Co. v. Sawyer concerned an Executive Order issued by President Truman which directed the Secretary of Commerce to take possession of most of the steel mills and to keep them operating. The President had taken this action because of an impending strike in the steel industry which threatened production during the Korean Conflict. The steel companies challenged the presidential order on the basis that it had not been authorized by any Congressional statute or constitutional provision.

In his classic concurring opinion, Justice Jackson enunciated his understanding of the separation of powers as a doctrine which both preserves democracy and protects individual liberties:

119 Ibid. at 246-47. See also Hirabayashi v. United States, 320 U.S. 81 (1943).

$120 \quad$ Ibid. at $245-46$.

121 P. Irons, Justice at War (Oxford: Oxford University Press, 1983) at viii.

122 Korematsu v. United Slates, 584 F. Supp. 1406, (N. D. Cal.1984), and the note in Cohen and Varat, supra note 2 at 701. The writ of coram nobis corrects errors of fact and not of law. The Supreme Court's majority decision remains the law, but it has very limited application.

123 C.S. Lewis, "The Inner Ring" in Screwtape Proposes a Toast and Other Pieces (Glasgow: William Collins Sons \& Co., 1978) 28 at 37. 
The actual art of governing under our Constitution does not and cannot conform to judicial definitions of the power of any of its branches based on isolated clauses or even single Articles torn from context. While the Constitution diffuses power the better to secure liberty, it also contemplates that practice will integrate the dispersed powers into a workable government. It enjoins upon its branches separateness but interdependence, autonomy but reciprocity. ${ }^{124}$

Jackson asserted a functional theory which related presidential authority to congressional power in the American system of government. When a President acts pursuant to an expressed or implied congressional authorization, he (she) has maximum authority. He (she) possesses all of his (her) own power plus all power which Congress can delegate. ${ }^{125}$ Those who challenge this action have the burden of persuasion. If the President acts in the absence of a congressional grant or denial of authority, he (she) can rely on his (her) own independent powers, but there is a "zone of twilight" in which the President and Congress may have concurrent authority, or the power distribution is uncertain. ${ }^{126}$ Congressional inaction could permit a President to take action. Finally, if the President takes action which is incompatible with the express or implied will of Congress, his (her) power is at its lowest point, for he (she) can only rely upon his (her) constitutional power minus that of Congress. ${ }^{127} \mathrm{~A}$ court will be careful in its analysis because the equilibrium of power between the political branches will be affected by any decision.

Jackson held that the Steel Seizure case had to be considered under the third classification because Truman's action was incompatible with the will of Congress expressed in three statutory policies concerning the grounds and methods for seizure of industrial properties. The President did not possess the power to seize the industries as Commander-in-Chief. ${ }^{128}$ The executive power under the "take care" clause had to be balanced against the due process clause which protected property. ${ }^{129}$ The concept of inherent powers was too nebulous to provide a basis for a presidential claim. ${ }^{130}$

Justice Jackson articulated a flexible theory of practical decision-making by separated institutions which share power. The President possesses enumerated powers which are to be interpreted flexibly. Outside of these powers, Congress must have the opportunity to participate in policy formulation. The courts are to be active in scrutinizing challenges to presidential authority in order to preserve the equilibrium of the constitutional system. In this way, judicial review promotes the democratic scheme of constitutional government. Individual liberties would be better protected because the inherent friction among the branches and the division of power would help to "save the people from autocracy." ${ }^{131}$ Unlike Korematsu, in which the two political branches were united, the Steel Seizure case is viewed as a situation in which the branches were in apparent disagreement. Because Congress remained silent and its position had to be

Steel Seizure case, supra note 113 at 635.

Ibid. at 635-37.

lbid. at 637.

Ibid. at 637-38.

lbid. at 644 .

Ibid. at 646.

Ibid. at 646-47.

Brandeis J., dissenting, in Myers v. United States, 272 U.S. 52 at 293 (1926). 
gleaned from a past statute, Jackson warned it not to rely upon the Supreme Court to protect its power. ${ }^{132}$

\section{Conclusion}

A careful analysis of the judicial career of Robert $\mathrm{H}$. Jackson provides many insights regarding the nature of the judicial function, the relationship of judicial review to democratic theory, and the effect of extrajudicial activities upon the perception and the reality of independence and impartiality. It also reveals the sophisticated interplay of choice and chance in the personal and professional formation of a twice gifted judge.

Jackson's theory of judicial review is complex because its evolutionary formulation and practical application were affected greatly by the varied experiences of his long legal and public service careers, and by the powerful forces which were operating in American legal and political thought. He attempted to separate law from partisan politics, and to rely upon procedure and neutral principles to give his theory increased legitimacy. Like Justice Cardozo, he adopted the style of a common law judge who applies broad principles to the particular circumstances of a case with a moderate degree of adaptability.

Jackson recognized that there is an inherent tension between judicial review and democracy. He attempted to minimize this tension by supporting judicial deference to the actions of the political branches. In certain cases, however, he was not reluctant to strike down a statute if he believed that it conflicted with a constitutional right. In this way, he refused to permit judicial review to be reduced to a meaningless procedure.

In economic matters, Jackson deferred to the national government, while in other cases he strongly supported procedural due process, especially following his Nuremberg experience. In civil liberty cases, Jackson defended the right to private beliefs, but he was less sympathetic to those who would proselytize. He sought to balance individual liberty with public order. During periods of international conflict, he would not allow the Court to be used as a rubber stamp for national policy that infringed upon civil liberties. His concurring opinion in the Steel Seizure case is considered an enduring contribution to the jurisprudence concerning the separation of powers doctrine. ${ }^{133}$

The influence of Jackson's judicial review theory has been reduced because of its complexity, unpredictability, and its expression in dissents and concurrences. Like most judges, he reflected often upon his views. This reconsideration sometimes produced inconsistencies in his jurisprudence as he balanced "the values of continuity against those of improvement."134 Nevertheless, many of Mr. Justice Jackson's opinions are still viewed as the professional work of a gifted judge who understood deeply the practical functions of the American government, and the proper role of the judiciary in that democracy.

Steel Seizure case, supra note 113 at 654.

G. Gunther, Constitutional Law, 12th ed. (Westbury, New York: Foundation Press, 1991) at 322, footnote 4.

Gerhart, supra note 8 at 466. 